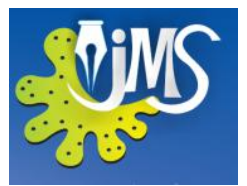

\title{
Exploring Gendered/Sexed Coporeality in Selected Twentieth-Century African American Women's Writings Towards an Alternative Theory of Gendered/Sexed Embodiment
}

\author{
Gayathri Madhurangi Hewagama
}

Department of English, University of Peradeniya, Sri Lanka

\begin{abstract}
Given the general primacy of the gendered/sexed subject that even seems to demarcate the human from the non-human, one's gendered/sexed identity gains an originary significance over other identity categorizations such as race, class, ethnicity etc. Gender/sex seen as an effect of a mainstream patriarchal ideology of heterosexuality, further assumes and validates/naturalizes a gendered/sexed corporeality (an assumed "reality"). Such a discourse then makes available a "woman's body" by giving primacy/recognition to heterosexual difference, on the basis of which discrimination and exploitation are enacted.

What I aim here is to problematize this heterogendered/sexed (gender is always already heterogendered) binary (not to say that sexuality or sexual difference/identity does not matter), by claiming that it is the assumed primal significance of heterogender/sex that is the mainspring of societal sexism. And it is only through a disruption of the very moment of discursive recognition/discrimination/interpellation of the "woman's body," that sexist discourses can be subverted. In the above light, the apparent reinforcement of the heterogendered/sexed binary and "black difference" in selected twentieth-century African American women's writing seems at loggerheads with my theoretical problematizations. However, these writings, read from a particular location, also open up a space of ambivalence; for, though beginning in heterogender/sex, these texts have the potential to look forward to a future freedom that transcends constraints generated by the "woman's body."

Thus, I will locate my study in selected African American texts by women (for instance, Toni Morrison's Song of Solomon, poetry by Nikki Giovanni, Lucille Clifton, etc.) while drawing from poststructural theoretical sources such as Judith Butler, bell hooks, Monique Wittig and Helene Cixous.
\end{abstract}

KEYWORDS: heterogender/sex, woman, corporeality, freedom, body corresponding author: Gayathri Madhurangi Hewagama eMail: gayathri_hewagama@yahoo.com 


\section{INTRODUCTION}

THEORETICAL APPROACH : "Can sexual difference be equated with other categories of difference? Is one's sexual identity constructed in the same way, does it operate on the same level, as one's racial or class identity; or is sexual difference a different kind of difference from these others?" (Emphasis added, Joan Copjec, Sex and the Euthanasia of Reason 18). In tandem with Copjec's above deliberation on the general primacy of the gendered $/$ sexed $^{1}$ subject, I would like to pose a fundamental question that has continued to trouble me from the moment I became critically aware of my gendered/sexed positionality: Why is one's gendered/sexed identity so important that it seems to gain an originary significance over such other identity categorizations?

\section{Judith Butler asks:}

Are there ever humans who are not, as it were, always already gendered? The mark of gender appears to 'qualify' bodies as human bodies; the moment in which an infant becomes humanized is when the question, "is it a boy or girl?" is answered. Those bodily figures who do not fit into either gender fall outside the human, indeed constitute the domain of the dehumanized and the abject against which the human itself is constituted. (Gender Trouble 111)

In the given scenario then, this different kind of difference can be seen as gaining primacy over other such identity categorizations, as an effect of a mainstream patriarchal ideology of gender/sex, that assumes, then validates/naturalizes a pre-

\footnotetext{
${ }^{1}$ I would like to use these terms interchangeably, both as discursive constructs that are materially produced in society.
}

existent gendered/sexed corporeality, ${ }^{2}$ which seems to accumulate meaning via race, class, ethnicity etc. This gendered/sexed corporeality further springs from a heterogendered/sexed discourse that seeks to perpetuate the manwoman binary. However, what is most striking about the given extract is that, gender/sex is considered by Butler as even differentiating the human from the non-human.

Likewise, through this binary discourse of heterogender/sexuality, a particular "woman's body" comes into being/becomes as an ideological effect; from dress to behavior, from walk to talk, her body and her bodily gestures begin to represent a particular corporeality, that not only becomes subject to a gaze from without but also a gaze from within. This woman's body not only undergoes ideological containment in the form of sociopolitical, religio-cultural norms and constraints of the community in which it lives, but also internalizes such societal expectations to such an extent that it polices itself. Wherever she is, she will not be able to escape her gendered/sexed subjectivity.

This body is also racialized, and classed, amongst other things. It is judged upon; it has a shape; hour glass, pear, triangle... It moves in a scale of desirability; one culture finds curves more attractive than another which worships size-zero figures. How healthy is this body? Is it oppressed and assaulted? One asks. Yet, what looms over and above this heterogeneity of identifications is the fact that it is a "woman"; that somehow, everything that happens to it can be rationalized by its

\footnotetext{
${ }^{2}$ In the term, "corporeality," I would like to nuance the notion of "reality" or the sense of naturalization that becomes an undercurrent in theories of the "body."

${ }^{3}$ This is also a heterogeneous body.
} 
gendered/sexed identity. There is indeed no escaping this woman's body. Or, does one want to?

\subsection{Background/Literature Survey}

In writings by selected ${ }^{4}$ twentieth-century African American women, such as Nikki Giovanni, Lucille Clifton, Toni Morrison, Maya Angelou, Gwendolyn Brooks, June Jordan etc., I see a clear articulation of the above corporeality in the form of a woman's body, and hence, an identifiable gendered/sexed binary, which is put to multiple aesthetic and discursive uses. On the one hand, there is a preliminary differentiation of bodies along the axes of gender/sex, race and class; where a black woman's body is identified in opposition to not only a black man's body, but also a white man's body and a white woman's body. A black working class woman's body may stand against a white middle class woman's/man's body and the like.

Likewise, Gwendolyn Brook's “The Lovers of the Poor" and "A Bronzeville Mother Loiters in Mississippi. Meanwhile, a Mississippi Mother Burns Bacon" are fine examples of the differentiation of a racialized and classed woman's body. In the former, she contrasts the ladies from the "Ladies' Betterment League" (which is a reference to the white, middle-class women who worked for their feminist cause) who are delicate and "barbarously fair," with an image of a working class black woman, whose "substantial citizenness/...arms akimbo, almost fills a door." In a more intensely contrasting duo, in the latter work, a white woman is seen to beautify herself

\footnotetext{
${ }^{4}$ They are not representative of all works by African American women of the period.
}

to look worthy in the eyes of her husband who sent a "dark villain" to his death protect her honour. "A Bronzeville Mother ..." is in fact referential of the case of Emmett Till, the black boy who was killed for his alleged assault on a white woman: "Then, before calling Him, she hurried/to the mirror with her comb and lipstick. It was necessary/to be more beautiful than ever/The beautiful wife."

Likewise, a black woman's body emerges who is clearly distinguished not only from men who are either black or white, but also from white women. From physical features to mannerisms and gestures, this differentiation is characterized by means of living, ideological stands and spiritual inclinations etc. that this body experiences.

\section{Gwendolyn Brooks}

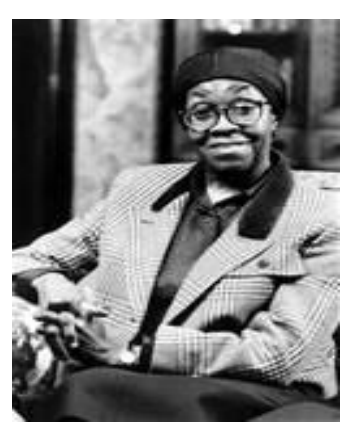

However, at the same time, at the base of this gendered / sexed differentiation lies a whole discourse on binary constructions, where the particular black woman's body that these writings represent subvert the contending concepts of morality-immorality, religiosity-profanity, passivity-violence, mind-body, reason-emotion, culture-nature etc., through a celebration/validation of the second term in these binaries, that is generally seen to invoke the Other.

For instance, Lucille Clifton's "Homage to my Hips" and "A Poem in Praise of my Menstruation" use conventional biological markers denoting female sexuality 
and physical weakness (respectively) and rearticulate them as causes for veneration and celebration:

these hips are big hips

they need space to

move around in.

they don't fit into little

petty places. these hips

are free hips.

...

... these hips are mighty hips.

these hips are magic hips.

$i$ have known them

to put a spell on a man and

spin him like a top! ${ }^{5}$

Audre Lorde's "Never Take Fire from a Woman" is a lesbian rediscovery of a woman's body, while June Jordan's "Poem about my Rights" is on how bodily exploitation (in the form of rape) can function as a catalyst for the articulation of freedom. Nikki Giovanni in "Ego Tripping" fashions the universe anew with a woman at the head as its creator:

\section{I sat on the throne}

Drinking nectar with Allah

I got hot and sent an ice age to Europe

To cool my thirst

My oldest daughter is Nefertiti

The tears from my birth pains

Created the Nile

I am a beautiful woman ${ }^{6}$

Such texts therefore, go onto find, in the very racist and sexist stereotypes fashioned on black/African American women, causes for

\footnotetext{
${ }^{5}$ http://www.poetryfoundation.org/poem/179615

${ }^{6} \mathrm{http}$ ///poetry.rapgenius.com/Nikki-giovanni-ego-trippingthere-may-be-a-reason-annotated
}

their celebration. All in all, these writings aim to establish a particular black difference, ${ }^{7}$ a black woman's body is projected not only as being discursively and/or materially distinguishable from other bodies, but also as being potent and desirable. This celebration of a mainly racial (and class specific) identity via a gendered/sexed corporeality, accommodates what Lilamani De Silva identifies as an "oppositional knowledge that subvert[s], contest[s], and challenge[s] constructs of [derogatory] knowledge obtained in history as regards the nature, history and lives of AfricanAmerican people ... [by] speak[ing] the African-American gendered subject into being" (107).

Such knowledge then aims to contest both a history of racist, sexist, classist segregation and exploitation, as well as a racist, sexist and classist ideology which sought to constrain African American women within taboo stereotypes. By thus subverting a site of exploitation into a site of empowerment, these twentieth-century African American women writers seem to fashion a potent identity through corporeality. Indeed, if the black woman's suffering, in specific reference to slave history, generated through bodily/corporeal experiences (manual labour, domestic violence, abortion, rape etc. ${ }^{8}$ ) then the body equally becomes the space from which liberation is sought. ${ }^{9}$

${ }^{7}$ Perhaps, also as a counter-conceptualization of "innate black barbarism."

${ }^{8}$ Thomas R. Frazier. Readings in African-American History.

9"'The Black body is reclaimed from the world of work and, in Marcuse's phrase, celebrated as an 'instrument of pleasure, rather than labour.' Sexuality therefore stands as not only an area of conflict in its own right, but as a symbol of freedom from the constraints of the discipline of wage" (Paul Gilroy 273). Alberto 


\section{MATERIALS AND METHODS}

Subsequent to the preceding theoretical and literary background, what I propose here may initially seem at cross purposes with the above. For, I find an entry-point into the foregone discussion on gendered/sexed corporeality, through an academic as well as an intensely personal interest, in seeking forays into a possible resolution of my confusions with $m y$ gendered/sexed identity; caught between multiple societal expectations and constraints due to being/becoming a "Sri Lankan, Sinhalese, Buddhist, middle-class, Englisheducated, married, child-free, thirty-year old woman," (amongst being other things) I see the very moment of discursive and ideological recognition/discrimination/interpellation of the woman's body/i.e. the heterogendered/sexed body, as the mainspring of societal sexism.

However, what I aim here is, in a sense, to both pull the rug under our feet and keep it too; to problematize the heterogendered / sexed binary is not to say that sexuality or sexual difference / identity does not matter. But this is

\footnotetext{
Melucci as quoted in Gilroy-"the central place they give to the body, and through it to an understanding of human beings as a part of the natural world. Blacks who live in 'the castle of their skin' and who have struggled to escape the biologization of their socially and politically constructed subordination are already sensitive to this issue. The attempt to articulate blackness as an historical rather than as a natural category confronts it directly .... Black artists have thus identified the body as a seat of desires and as a nexus of interpersonal relationships in a special way which expresses the aspiration that skin colour will one day be no more significant than eye pigment, and in the meantime announces that black is beautiful. Whether it is anti-racist universality or spurious racial classification which is being invoked, the black body bears some potent meanings" (308-309).
}

an effort, on the one hand, rather to disrupt the primal significance of heterogender / sex, which I consider as the mainspring of sexism in society, and on the other hand, to posit that a pre-existent / anteriorgendered / sexed corporeality is not necessary for the articulation of freedom.

In this regard, twentieth-century African American women's writing is of great relevance to the contemporary patriarchal discourse and ethos I inhabit/inhabits me, as a "Sri Lankan, Sinhalese, Buddhist, middle-class, English-educated, married, child-free, thirtyyear old woman." Although our histories and circumstances of life are vastly different, these works offer me a sense of potency and also an ambivalent site that could possibly turn itself into a space of agency. This study opens up not only an academic but also a very personal space for an alternative liberatory discourse, which would disrupt the numerous gender/sex markers, norms of behavior, codes of conduct that continue to constrain multiply constituted women's bodies in contemporary Sri Lanka.

In order to achieve the above purpose, I explore theories on gender/sex constitution, with specific relevance to the construction of the woman's body; texts such as Judith Butler's Gender Trouble, bell hooks' Ain't I a Woman: Black Women and Feminism, and "Postmodern Blackness," Gayatri Chakravorty Spivak's preface to Jacques Derrida's Of Grammatology, Monique Wittig's One is not Born a Woman, Helene Cixous's The Laugh of the Medusa etc.

The literary works that I use as a site where I locate my theoretical arguments comprise of a selected/restricted twentiethcentury African American poetry, and fiction by women, which specifically/conspicuously 
deal with the woman's body. To name a few: Toni Morrison's Song of Solomon, poetry by Nikki Giovanni, Lucille Clifton, Audre Lorde, June Jordan etc. These texts, though used as works which represent an identifiable trend in presenting the politics of a black woman's body, may not be taken as representational of all works by African American women writers of the period. In fact, I consider my study as mainly contributory to critical theory on gendered/sexed embodiment, while being located in a particular literary site that provides the necessary entry-point into a discourse on alternative embodiment.

\section{ANALYSIS}

In the above light, the apparent reinforcement of the heterogendered/sexual binary in the strong articulation of a particular woman's body and a black difference, in selected twentieth-century African American women's writing seems at loggerheads with my theoretical problematizations. However, these writings, read from a particular location, also open up a space of ambivalence and it is in this interstitial space that a possible liberation can be found.

There are many "black women's bodies" different from each other, never one, but multiple; these bodies subvert the existing derogatory stereotypes and bring into crisis the binary constructions of morality-immorality, religiosity-profanity, passivity-violence, mindbody, reason-emotion, culture-nature etc., through a celebration/validation of the second term in these binaries, that is generally seen to invoke the Other; and above all, there is a prevalent sense of surrealism in the very corporeality of these women's bodies, that seems to seek for a liberation beyond the realities of gender/sex, race, class and the body.

In that case, in a deconstructive gesture, it is in this difference / differment of the woman's body rather than in difference, that a possible disruption of the binary can occour ${ }^{10}$. One becomes uneasy, unsure; just like my woman's body which I simultaneously desire and deride. Moreover, though beginning in heterogender/sex, these texts thus convey a sense of freedom that transcends constraints generated by corporeality.

Likewise, Nikki Giovanni in "Ego Tripping" makes use of a surreal image of a woman-creator who is seen as foundational in human civilization. Added to her revelry in the secular, she is passionately in love with her own body, her self; in fact, she is "so hip even [her] errors/are correct." She is a "gazelle so swift/so swift you can't catch [her]," so fluid that you can't "comprehend [her] except by [her] permission." Indeed, her being, whatever that may be, is forever deferred. And at the end of the poem, with obvious reference to the mythological "Flying African," she flies towards her freedom; "I mean ... I ... can fly/Like a bird in the sky ...."

On a similar vein, Lucille Clifton in "A Poem in Praise of My Menstruation" and "Homage to my Hips" invoke stereotyped attributes and functions of a (African American) woman's body just so that she could celebrate their potency. In the former,

10 "We could thus take up all the coupled oppositions on which philosophy is constructed, and from which our language lives, not in order to see opposition vanish but to see the emergence of a necessity such that one of the terms appears as the difference of the other, the other as differed within the systematic ordering of the same" (Derrida, Of Grammatology 148). 
menstrual blood is figured as a core element on which human civilization is built, while in the latter she praises the rounded and large hips as marking the potent presence of the woman's body. Here too the real and the unreal are confused and disrupted when these "magic hips ... go where they want to go."

In fact, it is this sense of airiness, or weightlessness of one's constitution that is seen as giving one mobility; to go where they want to go; to fly. Though beginning in solid identity-gendered/sexed, racialized, classed subjectivity-these women's bodies eventually gain fluidity and motion in the lightness of a more flexible subject position; a subject position that is porous enough for them to "slip through."

The role that Pilates plays in Toni Morrison's Song of Solomon is therefore of momentum at the current point of discussion, since she too is a representation of a (sur)real freedom-searcher who can "fly" towards her liberation, though with her feet on solid ground; "Without ever leaving the ground, she could fly" (336). She is the subversive, independent African American woman figure in Morrison's novel who can in fact be seen as a "pilot" guiding Milkman's life and fate; a boy-man who is in search of his Black roots and freedom.
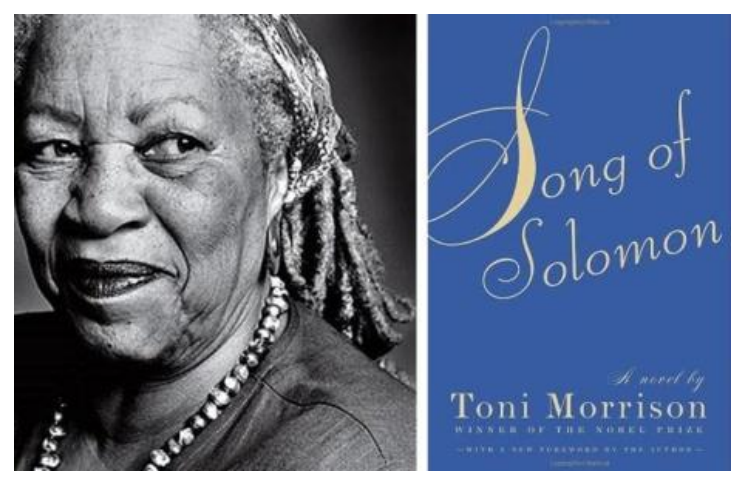

Not only does Pilate challenge the concepts of the real and the unreal, but she also disrupts the human and the non-human, the normal and the abnormal for she is born minus a naval. It is the smooth, undimpled skin on her stomach that drives many a man (and also women) from her, as she is seen as a creature not-from-this-world, "something God never made" (144): "It was the absence of a naval that convinced people that she had not come into this world through normal channels; had never lain, floated, or grown in some warm and liquid place connected by a tissue-thin tube to a reliable source of human nourishment"(114).

However, instead of projecting the lack of a naval as an abnormality, Morrison explores the idea that Pilate is a woman who cannot be constrained by the code of normalcy as prevalent in her times. Morrison instead portrays the latter as a strong, free, independent spirit who challenges the abject circumstances in her life. In the fluidity of her being, she learns to fly towards her freedom. Therefore, the particular embodiment/corporeality of Pilate takes her towards a sense of liberation that is beyond the 'body'; a flexible space opens up where she could find her own individual freedom.

Hence, all the above works use the corporeal to go beyond the corporeal; by providing the reader with multiple and ever differing images of the embodiment of women, and by challenging and disturbing the assumedly clear duality of binaries, they validate the idea that what is a construct can be perpetually renewed through reconstruction. Likewise, let the woman's body free and let her "fly." 


\section{RESULTS AND DISCUSSION}

In light of the above literary analysis, I can confidently say that, although ages and cultures apart, the potential that the above discussed African American women's writing offers in searching for a liberation from the constraints of gendered/sexed subjectivity, is of great relevance not only to my immediate subject position but also to the socio-cultural ethos that one inhabits/inhabits one as a woman in a Sri Lankan context.

Likewise, it is the understanding of the contractedness of all identity which such works give, that paves the way towards a reconstruction of prevalent constraining images of womanhood. For critics to the likes of Butler and hooks, this fluidity of identity is what attributes deconstruction and poststructural gender theory their liberatory potential. For instance, consider the following extract in hook's "Postmodern Blackness," where she goes onto elaborate on how a deconstructive understanding can be contributory to the search for a lasting liberation, with reference to a black context:

[...] The postmodernist focus on the critique of identity appears, at first glance, to threaten and close down [possibilities] ... We should indeed be suspicious of postmodern critiques of the 'subject' when they surface at a historical moment when many subjugated people feel themselves coming to voice for the first time ... However, postmodern critiques of essentialism which challenge notions of universality and static over-determined identity within mass culture and mass consciousness can open up new possibilities for the construction of the self and the assertion of agency" (6).
Even though it is not easy for a woman to shed one positionality and don a new guise in the name of a reconstructed identity-as we are all discursive constructs who are materially produced-the disruption of the rigid binary discourse would at least open up possible alternative sites from where a sense of liberation can be initiated.

\section{CONCLUSION}

Then, to say that women fall into a single group due to their gender/sex, or to say that women exist as totally isolated individuals would be an intellectual faux pas. The former argument borders on a misleading sense of homogeneity and clan-consciousness, while the latter generates an unwholesome isolationism. Instead, the urgency of the current moment in history-which can be unsatisfactorily summed up as the twenty-first century socio-political, economic circumstances that women's bodies inhabit/which inhabit them in present day Sri Lanka-is to challenge the constraints of the need for an anterior/preexistent subject to cause its liberation.

Hence, each corporeal image of woman should not strive to loyally mimic a pre-existent notion of what it is to be a particular gendered/sexed being, but should aim to present positive and potent figures who are characterized beyond gender/sex. For as long as the man-woman binary is reinforced and naturalized via corporeality so long will live the oppressive patriarchal structure. Women and men are more than women and men, and it is only a disruption of this differentiation into a deferment that can bring about a lasting solution to the oppressions and injustices that occur in the name of gendered/sexed difference. 


\section{REFERENCES}

BALIBAR, ETIENNE. (ed) (1996). "Subjection and Subjectivation."Supposing the Subject. London: Verso

BELSEY, C. AND MOORE J. (ed) (1990).

"Introduction: The Story So Far." The Feminist Reader: Essays in Gender and the Politics of Literary Criticism. Eds. Oxford: Blackwell.

BENNET, MICHAEL. (2000). Recovering the Black Female Body. New York: Rutgers.

BUTLER, JUDITH. (1993). Bodies that Matter: On the Discursive Limits of Sex. London: Routledge, 1993. Gender Trouble. (1990) London: Routledge. "Performative Acts and Gender Constitution: An Essay in Phenomenology and Feminist Theory." (ed) (2010) Feminist Theory Reader: Local and Global Perspectives. New York: Routledge.

CIXOUS, HELENE. (ed) (1996). "Conversations." Feminist Literary Theory: A Reader. Oxford: Blackwell.

DERRIDA, JACQUES. (1990). "Structure, Sign and Play in the Discourse of the Human Sciences." Writing and Difference. Trans. Alan Bass. London: Routledge.

FANON, FRANTZ. (1967). Black Skin, White Masks. New York, Grove.

FUSCO, COCO. (1995). English is Broken Here: Notes on Cultural Fusion in the Americas. New York: The New Press.

GATES. HENRY LOUIS. (1989). The Signifying Monkey: A Theory of African American Literary Criticism. New York, Oxford.

GILROY, PAUL. (1987). There Ain'tNo Black in the Union Jack: The Cultural Politics of Race and Nation. London: Unwin.

MORRISON, TONY. (1998). Song of Solomon. London: Vintage. 